\title{
PENGARUH MODEL PBM DALAM PEMBELAJARAN PPKn TERHADAP KEMAMPUAN BERPIKIR KRITIS DAN SIKAP DEMOKRATIS
}

\author{
Risti Aulia Ulfah ${ }^{1}$, Danang Prasetyo ${ }^{2}$, Marzuki $^{3}$ \\ P-MKU Universitas Negeri Yogyakarta ${ }^{1}$, STIPRAM Ambarrukmo Yogyakarta ${ }^{2}$, \\ Prodi PPKn Program Pascasarjana Universitas Negeri Yogyakarta ${ }^{3}$ \\ email: ristiaulia@gmail.com ${ }^{1}$, danang.ppsuny@gmail.com ${ }^{2}$, marzuki@uny.ac.id ${ }^{3}$
}

Naskah diterima: 11/10/2018 revisi: 26/10/2018 disetujui: 28/10/2018

\begin{abstract}
Abstrak
Penelitian ini memiliki tujuan untuk mengetahui (1) pengaruh model pembelajaran berbasis masalah/PBM terhadap kemampuan berpikir kritis, dan (2) pengaruh model pembelajaran berbasis masalah/PBM terhadap sikap demokratis bagi peserta didik dalam pembelajaran PPKn di Sekolah Menengah Kejuruan Negeri 1 Magelang. Penelitian ini adalah penelitian quasi experiment. Data dianalisis dengan menggunakan uji-t. Hasil penelitian ini adalah. (1) Terdapat pengaruh yang signifikan model pembelajaran berbasis masalah/PBM terhadap kemampuan berpikir kritis peserta didik dalam pembelajaran PPKn yang terbukti nilai $\mathrm{t}$ hitung $>\mathrm{t}$ tabel pada taraf signifikansi $\alpha=0,05$ $(2,557>2,000)$. (2) Terdapat pengaruh yang signifikan model pembelajaran berbasis masalah/PBM terhadap sikap demokratis peserta didik dalam pembelajaran PPKn terbukti nilai $\mathrm{t}$ hitung $>$ dari $\mathrm{t}$ tabel pada taraf signifikansi $\alpha=0,05(5,332>2,000)$.
\end{abstract}

Kata kunci: pendidikan kewarganegaraan, model pembelajaran, kemampuan berpikir kritis, sikap demokratis

\section{THE EFFECT OF PBM MODEL IN PPKn LEARNING ON CRITICAL THINKING ABILITY AND DEMOCRATIC ATTITUDES}

\begin{abstract}
This study aims to determine (1) the effect of problem-based learning models on critical thinking skills, and (2) the effect of problem-based learning models on democratic attitudes for students in learning PPKn at Magelang 1 State Vocational High School. This research is a quasiexperimental study. Data were analyzed using t-test. The results of this study are. (1) There is a significant effect of the problem-based learning model on students' critical thinking skills in PPKn learning which is proven by the value of $t$ count $>t$ table at the significance level $\alpha=0.05$ (2.557> 2,000). (2) There is a significant effect of the problem-based learning model on the democratic attitudes of students in PPKn learning as evidenced by the value of $t$ count $>$ from $t$ table at the significance level $\alpha=0.05(5.332>2,000)$.
\end{abstract}

Keywords: citizenship education, learning model, critical thinking skills, democratic attitudes. 


\section{PENDAHULUAN}

Pendidikan mempunyai kontribusi penting dalam upaya menhasilkan sumber daya manusia yang berkualitas. Salah satunya melalui Pendidikan Pancasila dan Kewarganegaraan (PPKn) sebagai mata pelajaran yang memiliki kedudukan strategis untuk mencapai tujuan pendididikan nasional. Esensi pembelajaran PPKn yakni sebagai sarana pembentukan dan pengembangan peserta didik menjadi warga negara yang baik dan berkualitas, sekaligus untuk menumbuhkan nilai-nilai demokrasi dan kemampuan berpikir kritis bagi peserta didik. Terlebih lagi pembelajaran PPKn pada kurikulum 2013 yang bertujuan menjadikan peserta didik aktif, kooperatif, dan kritis sehingga mampu memberikan bekal kepada pengalaman-pengalaman dan praktik konsep-konsep kehidupan berbangsa dan bernegara dalam ruang kelas maupun di luar kelas (Samsuri, 2013, : 6-7).

Kemampuan berpikir kritis perlu diasah dan ditumbuhkembangkan, supaya peserta didik dapat menganalisis dan memecahkan permasalahan baik dalam proses pembelajaran maupun kehidupan masyarakat. Terlebih lagi di abad ke-21 ini, salah satu kompetensi yang harus dimiliki warga negara yaitu berpikir kritis. Kemampuan berpikir kritis (critical thinking) berarti kemampuan yang dimiliki peserta didik unuk memanfaatkan potensipotensi intelektualnya untuk mampu menyelesaikan permasalahan secara sistematis, rasional maupun empiris. Penerapannya dengan cara menghubungkan permasalahan dengan penyebabnya, mampu menampilkan logika yang rasional sehingga dapat diterima oleh pikiran orang lain. Selain itu, kemampuan berfikir kritis harus didukung dengan data yang akurat (Rosyada, 2004: 285).

Melalui pembelajaran PPKn Peserta didik diharapkan mampu mengembangkan sikap demokratis. Hal tersebut sejalan dengan pernyataan Somantri (2001: 299) bahwa pendidikan kewarganegaraan merupakan program pendidikan yang memiliki inti matei demokrasi politik. Materi ini dapat diperluas dengan memanfaatkan sumber-sumber pengetahuan lainnya, pengaruh budaya positif dari pendidikan formal di sekolah, kebiasaan masyarakat seperti adat dan budaya (Feriandi, 2017) , dan memaksimalkan peran orang tua. Kajian mengenai peran orang tua dalam pembelajaran PPKn dapat di lihat dari penelitian yang dilakukan oleh Marzuki, \& Feriandi (2016) yang membuktikan bahwa orang tua memiliki peran yang lebih besar jika dibanding guru. Sumber tersebut harus dikelola untuk membiasakan peserta didik supaya mampu berpikir kritis, analitis, bersikap dan bertindak demokratis dalam mempersiapkan diri hidup dengan jiwa demokratis berdasarkan Pancasila dan UUD 1945. Hal senada juga di ungkapkan oleh Soenarjo (2011) bahwa PPKn sejatinya memiliki tugas utama untuk membuat siswa kritis terutama dalam hal pluralisme, musyawarah, kebebasan nurani,persamaan hak dan kewajiban, serta kejujuran dalam pemufakatan.

Pendidikan Pancasila dan Kewarganegaraan menjadi salah satu mata pelajaran wajib yang harus ditempuh oleh peserta didik baik di jenjang Sekolah Dasar (SD), Sekolah Menengah Pertama (SMP), maupun Sekolah Menengah Atas, Sekolah Menengah Kejuruan, dan Madrasah Aliyah (SMA/SMK/MA). Pendidikan Pancasila dan Kewarganegaraan (PPKn) memiliki tiga kompetensi yang terdiri dari pengetahuan, ketrampilan dan sikap (civic knowledge, civic skill, and civic disposition). Diantara kompetensi tersebut terdapat dua kompetensi yang menjadi faktor penting untuk menyiapkan peserta didik menjadi warga negara yang baik (good citizen) yaitu civic knowledge (berpikir kritis) dan civic disposition (sikap demokratis). Warga negara baik merupakan warga negara yang sadar melaksanakan hak dan kewajibannya secara seimbang. Kesadaran terhadap hak 
dan kewajiban yang dimiliki setiap warga negara mampu menjadikan seorang warga negara yang berfikir kritis, partisipatif, dan bertanggung jawab (Cholisin, 2005: 1). Salah satu cara yang dapat dilakukan oleh guru untuk menumbuhkan kemampuan berpikir kritis dan sikap demokratis peserta didik yaitu dengan melakukan inovasi model pembelajaran, sehingga mampu menghasilkan manusia yang berkarakter dan berkualitas.

Sampai saat ini, mata pelajaran PPKn dalam kegiatan pembelajaran terkesan lebih banyak diajarkan (tought), bukan dipelajari (learned). Dengan cara ini peran guru yang lebih dominan, sehingga situasi kelas lebih bersifat dominative bukan integrative. Begitu juga dampak instruksional dan pengiringnya belum dapat tercapai. Pembelajaran di kelas lebih bersifat kognitif (knowledge) (Winataputra, 2012: 86). Winataputra (2012: 18) menyatakan bahwa untuk mencapai tujuan pendidikan kewarganegaraan yang religius dan mencerdaskan yang dalam hal ini tidak lebih banyak ditekankan pada aspek pengetahuan semata maka diperlukan model-model pembelajaran yang kreatif dan inovatif. Model pembelajaran yang berbasis pada kreatifitas dan inovasi manjadikan peserta didik mampu mengkaji gagasan, mengunakan instrumen, praktek demokrasi, membiasakan menerapkan konsep secara kontekstual sebagai kesatuan proses belajar. Model pembelajaran yang tepat untuk tujuan tersebut yaitu pembelajaran berbasis masalah (problem based learning).

Model pembelajaran berbasis masalah/PBM (problem based learning) yaitu model pembelajaran yang mengkaji permasalahan permasalahan yang aktual sebagai bahan kajian bagi peserta didik untuk belajar berpikir kritis, memiliki keterampilan memecahkan masalah serta memperoleh pengetahuan pemecahan masalah (Shoimin, 2014: 130). Kelebihan dari model pembelajaran berbasis masalah/PBM yakni peserta didik dibiasakan mempunyai kemampuan memecahkan masalah di kehidupan nyata, peserta didik memiliki kemampuan mengembangkan pengetahuan melalui proses belajar, dan peserta didik memiliki kemampuan berkomunikasi secara ilmiah melalui kegatan diskusi atau presentasi hasil penelitian. Massa (2008: 19) menyatakan bahwa dasar dari pembelajaran berbasis masalah adalah keaktifan peserta didik dalam proses belajar. Model ini berpusat pada peserta didik dengan cara diskusi dalam kelompok-kelompok kecil, menghasilkan informasi yang diperlukan untuk merespons, memecahkan masalah atau tugas tertentu. Prinsip dasar yang mendukung konsep PBL dimulai dari menemukan masalah dan teka-teki yang ingin dipecahkan oleh peserta didik.

Model pembelajaran berbasis masalah/PBM (problem based learning) disarankan untuk diimplementasikan pada belajar mengajar karena kemampuan memecahkan masalah harus dimiliki oleh peserta didik pada abad ke-21, yang dengan belajar pemecahan masalah peserta didik dapat mengaplikasikannya pada kehidupan sehari-hari. Pendidikan di abad ke-21 juga menekankan pada masalah di dunia nyata sehingga model pembelajaran ini sangat efektif untuk diterapkan karena melibatkan kecerdasan individu dan kelompok dari lingkungan untuk memecahkan masalah (Tan, 2003: 2).

Penerapan model pembelajaran berbasis masalah/PBM mampu menciptakan iklim demokrasi yang tercermin dari perilaku interaktif antara guru dengan peserta didik dan antarpeserta didik, yang dalam hal ini dapat menumbuhkan sikap demokratis. Perlu diterapkan model pembelajaran yang memberdayakan peserta didik di kelas sehingga kelas akan berubah dari yang bersifat dominatif menjadi integratif (Winataputra, 2012: 88). Penerapan pembelajaran PPKn dengan model pembelajaran berbasis masalah/PBM dapat menumbuhkan kemampuan berpikir 
kritis peserta didik. Peserta didik diminta memecahkan masalah yang diberikan oleh fasilitator/guru. Untuk memecahkan masalah tersebut peserta didik harus berpikir tingkat tinggi atau berpikir kritis.

Bukti meningkatnya kemampuan berfikir kritis dengan model pembelajaran berbasis masalah/PBM dikuatkan oleh hasil penelitian Murdiono (2010: 16) bahwa penerapan model ini dalam pembelajaran pendidikan kewarganegaraan mampu meningkatkan keterampilan kewarganegaraan (civic skill). Hal tersebut dapat diamati dari meningkatnya kemampuan analisis terhadap permasalahan aktual yang telah diidentifikasi saat proses belajar.

Model pembelajaran berbasis masalah/PBM (problem based learning) mempunyai unsur yang hampir sama dengan model pembelajaran penemuan (discovery learning). Model pembelajaran penemuan (discovery learning) mendorong peserta didik untuk belajar lebih aktif melalui keterlibatan aktif dengan mengunakan konsep-konsep dan prinsip-prinsip keilmuan. Guru mendorong peserta didik untuk belajar dari pengalaman dan melakukan percobaan sehingga mampu menemukan prinsip-prinsip untuk diri sendiri. Kelebihan model pembelajaran penemuan (discovery learning) yaitu memicu keingintahuan peserta didik, memotivasi peserta didik untuk melanjutkan percobaannya sehingga mampu menemukan jawaban. Peserta didik secara mandiri belajar memecahkan masalah dan mengembangan keterampilan berpikir kritis karena harus mampu menganalisis dan mengelola informasi (Suprihatiningrum, 2012, : 241-245).

Sekolah Menengah Kejuruan yang notabennya memiliki tanggung jawab menghasilkan lulusan siap kerja yang sesuai dengan bidangnya, namun terdapat permasalahan karena peserta didik cenderung antusias mengikuti pembelajaran produktif dibandingkan mengikuti pembelajaran PPKn, sehingga penting dilakukan pembelajaran PPKn dengan menggunakan model pembelajaran yang inovatif. Model pembelajaran yang cocok adalah model pembelajaran berbasis masalah/PBM (problem based learning) dan model pembelajaran penemuan (discovery learning). Proses belajar mengajar dengan menerapkan kedua model pembelajaran tersebut diharapkan mampu menumbuhkan kebiasaan berpikir kritis dan sikap demokratis peserta didik. Namun, kedua model pembelajaran tersebut tidak diteliti secara penuh, tetapi hanya satu model pembelajaran saja, yakni pembelajaran berbasis masalah, sedang pembelajaran berbasis penemuan diteliti hanya sebagai kontrol saja. Jadi, penelitian ini difokuskan untuk mengetahui pengaruh model pembelajaran berbasis masalah/PBM dalam pembelajaran PPKn terhadap kemampuan berpikir kritis dan sikap demokratis peserta didik di SMK Negeri 1 Magelang.

\section{METODE}

\section{Jenis Penelitian}

Desain penelitian yang digunakan dalam penelitian ini merupakan penelitian eksperimen semu atau biasa disebut dengan quasi experiment. Sedangakan desain yang digunakan yakni berupa randomized control group pretest and posttest design. Dengan desain tersebut peneliti memulai penelitian dengan menyiapkan sampel penelitian yang terdiri dari dua kelas yakni kelas eksperimen (kelas yang diberikan perlakukan) dan kelas kontrol (kelas yang tidak diberikan perlakukan khusus). Pengambilan kelas tersebut dilakukan dengan cara random atau acak, untuk menghindarkan data dari subjektifitas peneliti (Isaac \& Michael, 1981: 65). Guna mendapatkan hasil penelitian yang sahih, kedua kelas tersebut terlbih dahulu diberikan pre test guna mengukur kemampuan awal peserta didik. Harapan diberikan pre test yakni untuk memudahkan peneliti mengukur dan membedakan hasil akir perlakuan dengan 
menggunakan model pembelajaran berbasis masalah/PBM (problem based learning) serta model pembelajaran dengan basis penemuan (discovery learning). Setelah diberikan perlakuan pada kedua kelas tersebut maka peneliti memberikan post test guna menggukur peningkatan serta kemampuan akir yang telah di capai peserta didik.

\section{Waktu dan Tempat Penelitian}

Tempat penelitian yang dipilih yakni Sekolah Menengah Kejuruan Negeri 1 Magelang. Sekolah tersebut berlokasi pada Jalan Cawang No. 2 Magelang Jawa tengah. Sedangkan untuk waktu penelitian yakni dilaksanakan pada bulan Februari sampai April tahun 2018, atau lebih tepatnya di Semester Genap Tahun Pelajaran 2017/2018.

\section{Target/Subjek Penelitian}

Pada penelitian ini, peneliti memberikan perlakuan sebanyak empat kali, dan pada Kompetensi Dasar (KD) yang dipilih yakni mengenai menganalisis kasus pelanggaran hak dan pengingkaran kewajiban sebagai warga negara. Populasi yang dilibatkan dalam penelitian yakni seluruh peserta didik yang ada pada kelas $\mathrm{X}$ (sepuluh) Sekolah Menengah Kejuruan Negeri 1 Magelang tahun pelajaran 2017/2018, yang di dalamnya terdiri dari lima jurusan. Lima jurusan tersebut yaitu Elektronika, Otomotif, Mesin, Listrik, dan Bangunan yang masing-masing jurusan terbagi ke dalam empat kelas paralel yaitu kelas A, B, C, dan D.

\section{Prosedur}

Penentuan sampel didasarkan pada metode cluster random sampling atau kelas. Alasan pengunaan metode tersebut karena, dengan menggunakan metode tersebut maka masing-masing kelas $\mathrm{X}$ mendapat peluang yang serupa untuk menjadi sampel penelitian sehingga sampel yang terpilih terbebas dari subjektifitas peneliti. Setelah menggunakan metode cluster random sampling maka sampel yang di terpilih yakni kelas X Elektronika A dijadikan sampel sebagai kelas eksperimen yang dalam proses belajar mengajar mata pelajaran PPKn menggunakan model pembelajaran berbasis masalah/PBM (problem based learning) dengan jumlah 31 peserta didik. Sedangkan kelas X Mesin A sebagai kelas kontrol yang dalam proses belajar mengajar menggunakan model pembelajaran penemuan (discovery learning) yang berjumlah 29 peserta didik.

\section{Data, Intrumen, dan Teknik Pengumpulan Data}

Data dari penelitian ini berkaitan dengan proses pembelajaran PPKn pada KD menganalisis pelanggaran hak dan pengingkaran kewajiban, hasil pembelajaran PPKn pada aspek kognitif sebelum dan setelah dilakukan perlakuan dengan model pembelajaran, dan pembiasaan sikap demokratis di lingkungan sekolah baik pada proses pembelajaran maupun pada kegiatan ektrakulikuler. Data penelitian diukur dengan tes dan angket.

Penelitian ini menggunakan tes berupa multiple choice studi kasus pada KD menganalisis pelanggaran hak dan pengingkaran kewajiban untuk mengukur kemampuan berpikir kritis. Tes multiple choice studi kasus terdiri dari 50 soal. Responden hanya diminta untuk menjawab pertanyaan dengan opsi jawaban a,b,c,d, atau e. Skor penilaiannya apabila jawaban benar memperoleh nilai satu (1) dan apabila jawaban salah memperoleh nilai nol (0). Angket digunakan untuk mengukur sikap demokratis. Teknik pengumpulan data yaitu tes diberikan pada kelas X Elektronika A (kelas eksperimen) dengan kelas X Mesin A (kelas kontrol). Kisi-kisi tes ddasarkan pada indikator pada KD menganalisis pelanggaran hak dan pengingkaran kewajiban. Angket diberikan baik pada kelas kontrol maupun kelas ekserimen dengan teknik Skala Likert, dimana 
responden diminta untuk memilih pilihan yang tersedia selalu, sering, kadang-kadang, dan tidak pernah (Sugiyono, 2013: 93).

Penskoran pada angket didasarkan pada pilihan yang tersedia dengan melihat pernyataan positif atau negatif. Apabila responden dalam pernyataan postif memilih pilihan selalu mendapat skor (4), sering mendapat skor (3), kadang-kadang mendapat skor (2), dan tidak pernah mendapat skor (1). Sedangkan dalam pernyataan negatif, apabila responden memilih alternatif jawaban tidak pernah mendapat skor (4), kadang-kadang mendapat skor (3), sering mendapat skor (2), dan selalu mendapat skor (1). Adapun kisi-kisi angket sikap demokratis meliputi sikap toleransi, mampu menghargai perbedaan pendapat, memahami keanekaragaman, sikap terbuka, menjunjung tinggi nilai-nilai kemanusiaan, menjunjung harkat dan martabat manusia, pengendalian diri, kemanusiaan dan kebersamaan, kepercayaan diri, dan ketaatan pada peraturan yang berlaku.

Sebelum menggunakan tes kemampuan berpikir kritis dan angket sikap demokratis untuk instrument penelitian, peneliti terlebih dahulu melakukan validitas dan reliabilitas instrumen. Validitas dilaksanakan supaya instrumen yang digunaan benar-benar valid untuk digunakan sebagai instrument penelitian. Validitas instrumen pada proses persiapan penelitian ini berdasarkan pendapat ahli (expert judgment) dan validitas dengan responden dari luar tempat penelitian. Validasi dengan ahli berjumlah dua orang, para ahli memberikan saran untuk melakukan perbaikan instrumen penelitian.

Selanjutnya setelah instrumen diperbaiki, peneliti melakukan ujicoba instrumen di sekolah lain yaitu Sekolah Menengah Kejuruan Negeri 3 Magelang. Setelah dilakukan ujicoba instrumen baik tes kemampuan berpikir kritis maupun sikap demokratis, peneliti melakukan olah data menggunakan SPSS 21.0 for windows. Hasilnya didapatkan korelasi product moment yang menghasilkan taraf signifikansi sebesar 5\%. Adapun butir soal dan angket yang gugur tidak disertakan untuk penelitian. Berdasarkan hasil olah data tes kemampuan berpikir kritis terdapat 10 soal yang gugur sehingga hanya 40 soal yang dijadikan instrumen penelitian, sedangkan pada angket sikap demokratis terdapat 4 butir yang gugur sehingga hanya 27 pernyataan yang dijadikan instrumen penelitian.

Setelah dilakukan uji validitas, langkah selanjutnya yaitu melakukan uji reliabilitas dengan Alpha dari Cronbach untuk instrumen angket sikap demokratis dan KR21 untuk instrumen tes kemampuan berpikir kritis. Setelah dilakukan olah data menggunakan SPSS 21.0 for windows perolehan instrumen tes kemampuan berpikir kritis yaitu 0,917 dengan kategori tinggi dan angket sikap demokratis yaitu 0,909 dengan kategori tinggi.

Instrumen penelitian tes kemampuan berpikir kritis selain dianalisis dengan uji validitas dan reliabilitas juga melalui analisis soal yaitu uji tingkat kesukaran agar instrumen yang digunakan seimbang antara jumlah soal mudah, sedang, dan sukar. Setelah dilakukan olah data dengan menggunakan SPSS 21.0 for windows diperoleh delapan (8) soal pada kategori sukar, dua puluh lima (25) soal pada kategori sedang, dan tujuh belas (17) soal pada kategori mudah. Langkah selanjutnya yaitu melakukan uji beda, untuk membedakan responden yang pandai dan kurang pandai. Setelah peneliti melakukan analisis menggunakan software SPSS 21.0 for windows, peneliti mengetahui dua puluh empat (24) soal diterima dengan baik, empat belas (14) soal diterima dengan revisi, dua (2) soal direvisi, dan sepuluh (10) soal dibuang.

\section{Teknik Analisis Data}


Peneliti melakukan proses analisis data yang telah terkumpul dengan menggunakan uji-t (uji kesamaan dua rerata). Terdapat beberapa persyaratan yang harus dipenuhi melalui beberapa uji prayarat sebelum melakukan uji-t. Beberapa uji tersebut di antaranya adalah uji homogenitas, uji normalitas, dan uji jika data telah terbukti normal dan homogen maka peneliti dapat melanjutkanya dengan uji-t atau uji kesamaan dua rerata. Pada penelitian ini peneliti memilih mengunakan software statistik SPSS 21.0 for windows, alasan pemilihan tersebut karena dirasa cukup praktis dalam mengolah data serta menghasilkan hasil analisis yang tepat.

\section{HASIL DAN PEMBAHASAN}

Peneliti melakukan uji hipotesis dengan menggunakan uji-t (uji kesamaan dua rerata), namun sebelumnya harus melalui uji prasyarat analisis yaitu uji normalitas dengan uji KolmogorovSmirnov. Adapun untuk lebih mudah memahami hasil uji normalitas, peneliti rangkum ke dalam tabel di bawah ini.

Tabel 2. Hasil Uji Normalitas

\begin{tabular}{|c|c|c|}
\hline Data & Sig (p) & Keterangan \\
\hline $\begin{array}{l}\text { Pre-test kemampuan berpikir kritis } \\
\text { eksperimen }\end{array}$ & 0,310 & Signifikansi $>0,05=$ normal \\
\hline $\begin{array}{l}\text { Post-test kemampuan berpikir kritis } \\
\text { eksperimen }\end{array}$ & 0,056 & Signifikansi $>0,05=$ normal \\
\hline Pre-test kemampuan berpikir kritis kontrol & 0,305 & Signifikansi $>0,05=$ normal \\
\hline $\begin{array}{l}\text { Post-test kemampuan berpikir kritis } \\
\text { kontrol }\end{array}$ & 0,272 & Signifikansi $>0,05=$ normal \\
\hline Pre-test sikap demokratis eksperimen & 0,665 & Signifikansi $>0,05=$ normal \\
\hline Post-test sikap demokratis eksperimen & 0,438 & Signifikansi $>0,05=$ normal \\
\hline Pre-test sikap demokratis kontrol & 0,962 & Signifikansi $>0,05=$ normal \\
\hline Post-test sikap demokratis kontrol & 0,712 & Signifikansi $>0,05=$ normal \\
\hline
\end{tabular}

(Sumber: Hasil olah data mengunakan SPSS 21.0 for windows dengan melakukan uji Kolmogorov-Smirnov, 2018)

Berdasarkan hasil perhitungan uji normalitas pada Tabel 2 diketahui semua data berdistribusi normal pada $(\mathrm{p}>0,05)$. Selanjutnya peneliti melakukan uji prasyarat lain yaitu uji homogenitas dengan menggunakan uji F. Adapun untuk lebih mudah memahami hasil uji homogenitas, peneliti sampaikan melalui table 3 berikut ini.

Tabel 3. Hasil Uji Homogenitas

\begin{tabular}{|l|c|c|c|}
\hline \multicolumn{1}{|c|}{ Data } & F hitung & F tabel & Ket. \\
\hline Pre-test kemampuan berpikir kritis & 2,000 & 4,00 & Homogen \\
\hline Post-test kemampuan berpikir kritis & 0,757 & 4,00 & Homogen \\
\hline Pre-test sikap demokratis & 2,879 & 4,00 & Homogen \\
\hline Post-test sikap demokratis & 0,156 & 4,00 & Homogen \\
\hline
\end{tabular}

Berdasarkan hasil perhitungan uji homogenitas pada Tabel 3 diketahui bahwa data tersebut mempunyai varian yang homogen dengan $F_{\text {hitung }}<\mathrm{F}_{\text {tabel }}$. Hasil olah data tersebut telah memenuhi uji prasyarat analisis, dengan menggunakan uji normalitas maupun uji homogenita. Dengan demikian dapat dilakukan pengujian hipotesis dengan menggunakan uji-t (uji kesamaan dua rerata).

Hipotesis pertama menyatakan bahwa "Terdapat pengaruh model pembelajaran 
berbasis masalah/PBM (problem based learning) terhadap kemampuan peserta didik berfikir kritis dalam pembelajaran PPKn di Sekolah Menengah Kejuruan Negeri 1 Magelang". Analisis yang digunakan

Tabel 4. Rangkuman Hasil Uji t Kemampuan Berpikir Kritis Kelas Eksperimen dan Kelas

\section{Kontrol}

\begin{tabular}{|c|c|c|c|c|c|c|}
\hline $\mathbf{N}$ & $\overline{\mathbf{X}}$ & $\mathbf{d b}$ & to & $\mathbf{t t}$ & \multicolumn{2}{|c|}{ Sig. } \\
\cline { 6 - 7 } & & & & & $\mathbf{0 , 0 5}$ & $\mathbf{0 , 0 1}$ \\
\hline 29 & 79,91 & 27 & 29 & 79,91 & 27 & 29 \\
\hline 29 & 79,91 & 27 & & & & \\
\hline
\end{tabular}

(Sumber: Hasil olah data SPSS 21.0 for windows dengan uji t, 2018)

Berdasarkan hasil uji t pada Tabel 4 dapat diketahui pada taraf signifikansi $\alpha=$ 0,05 (2,557>2,000). Hasil uji tersebut menunjukkan adanya pengaruh signifikan penerapan model pembelajaran berbasis masalah/PBM (problem based learning) dalam pelajaran PPKn terhadap kemampuan berpikir kritis peserta didik di Sekolah Menengah Kejuruan Negeri 1 Magelang. Hasil perbandingan gain score antara kelas yang mengunakan model pembelajaran berbasis masalah/PBM (problem based learning) memperoleh skor yang lebih tinggi dibandingkan kelas yang mengunakan menggunakan uji t. Supaya lebih mudah memahami hasil uji t kemampuan berpikir kritis pada kelas eksperimen dan kelas kontrol, peneliti sajikan dalam tabel 4 di bawah ini. model pembelajaran penemuan (discovery learning). Perolehan gain score pada kelas eksperimen yang peneliti berikan perlakuan (treatmen) dengan model pembelajaran berbasis masalah/PBM (problem based learning) memperoleh 0,59 dengan tingkat keefektifan sedang, sedangkan kelas konrol memperoleh skor gain score pada kelas kontrol yang menggunakan model pembelajan penemuan (discovery learning) sebesar 0,39 dalam kategori efektif sedang. Hasil perbandingan gain score kemampuan berpikir kritis disajikan pada gambar 1 di bawah ini.

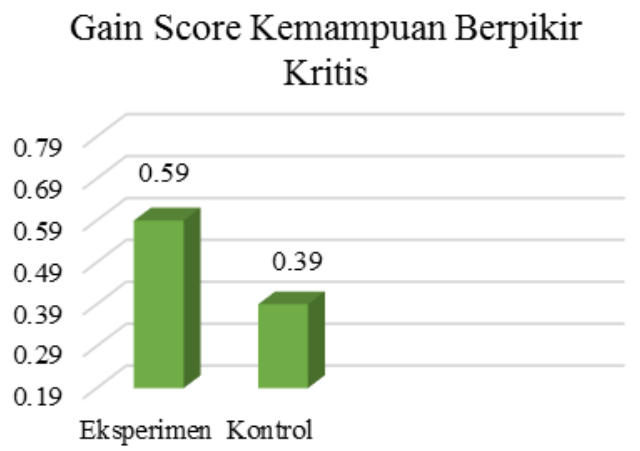

Gambar 1. Perbandingan gain score kemampuan berpikir kritis kelas eksperimen dengan kelas kontrol

Perbandingan kemampuan berpikir kritis dalam proses pembelajaran PPKn yang diajarkan dengan menggunakan model pembelajaran berbasis masalah/PBM (problem based learning) dengan peserta didik yang dibelajarkan dengan model pembelajaran penemuan (discovery learning) dapat dilihat berdasarkan nilai rata-rata (mean) sebelum dilakukan perlakuan dengan setelah dilakukan perlakuan. Perolehan skor mean kemampuan awal (pre-test) peserta didik pada kelas eksperimen mendapatkan nilai 
rata-rata 63,95. Sedangkan perolehan skor mean kelas kontrol mendapatkan nilai ratarata 67,24. Meskipun kemampuan awal (pre-test) perolehan skor mean kelas kontrol lebih tinggi dibandingkan kelas eksperimen, namun hasil kemampuan akhir (post-test) peserta didik kelas eksperimen yang diberikan perlakuan dengan model pembelajaran berbasis masalah/PBM (problem based learning) memperoleh nilai lebih tinggi dengan perolehan rata-rata 85,24 dibandingkan dengan kelas konrol yang dibelajarkan dengan model pembelajaran penemuan (discovery learning) dengan perolehan rata-rata 79,91. Hasil perbandingan nilai rata-rata (mean) kemampuan berpikir kritis kami sajikan pada gambar perbandingan skor mean di bawah ini.

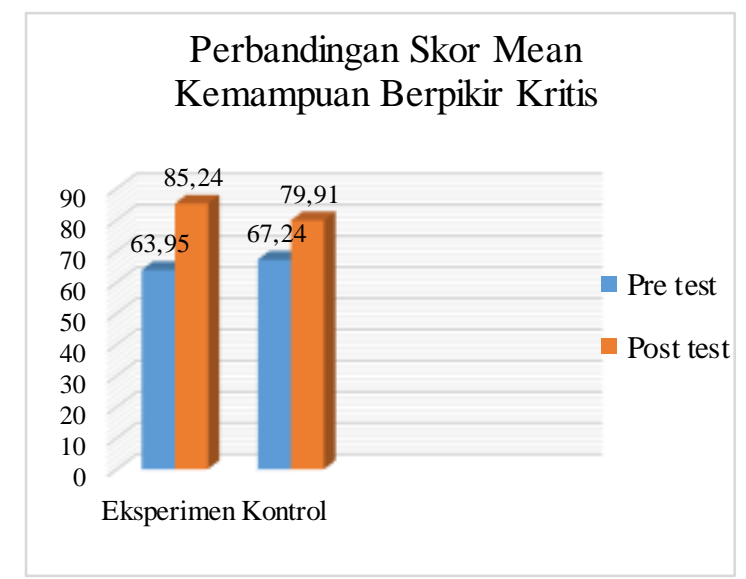

Gambar 2. Perbandingan skor mean kemampuan berpikir kritis

Berdasarkan hasil penelitian ini mampu menguatkan hasil penelitian Murdiono (2010: 16) bahwa implementasi model pembelajaran berbasis masalah/PBM dalam proses pembelajaran PPKn mampu meningkatkan partisipasi aktif peserta didik. Melalui model pembelajaran berbasis masalah/PBM telah mampu mengasah keterampilan kewarganegaraan (civic skiil). Hal tersebut dapat dapat diketahui dari peningkatan kemampuan peserta didik melakukan analisis terhadap permasalahan yang telah diidentifikasi oleh masingmasing kelompok saat proses belajar mengajar.

Selain itu, hasil penelitian ini sesuai dengan hasil penelitian yang pernah dilakukan oleh Yoswita, Pramudiyanti, \& Marpaung (2014, : 1-9) menunjukkan bahwa aktivitas peserta didik dalam bekerja sama dengan teman, melaksanakan kegiatan diskusi, dan mempresentasikan hasil diskusi kelompok mengalami peningkatan signifikan. Kemampuan berpikir kritis peserta didik mengalami peningkatan yang signifikan sebesar 32,57\%. Dengan demikian, proses belajar mengajar yang menggunakan model pembelajaran berbasis masalah/PBM memiliki pengaruh terhadap peningkatan kemampuan berpikir kritis peserta didik pada materi pokok pengelolaan lingkungan. Peserta didik juga memiliki tanggapan positif terhadap model ini. Peserta didik setuju mengunakan model ini karena mampu meningkatkan keaktifan, selalu mempelajari materi baru, memperoleh pengetahuan serta wawasan yang baru.

Hasil penelitian ini dapat menguatkan penelitian sebelumnya oleh Yang \& Chung (2009: 29) yang menunjukkan bahwa kelompok eksperimen secara signifikan mengungguli kelompok kontrol pada kemampuan berpikir kritis. Dengan demikian kemampuan berpikir kritis dapat mendorong peserta didik meningkatkan hasil belajar, keterampilan berbicara, dan lebih komunikatif. Peserta didik mempunyai keterampilan berbicara dan mempunyai 
keberanian, kepercayaan dan kemampuan mengekspresikan diri.

Perbandingan kemampuan berpikir kritis antara kelas yang diberikan perlakuan dengan model pembelajaran berbasis masalah/PBM (problem based learning) dengan kelas kontrol yang diajarkan dengan menggunakan model pembelajaran penemuan (discovery learning) disebabkan karena beberapa hal dalam proses pembelajaran PPKn. Salah satunya yaitu penerapan model pembelajaran yang tepat harus disesuaikan dengan kebutuhan peserta didik. Model pembelajaran masalah (problem based learning) memiliki ciri adanya permasalahan empiris sebagai konteks bagi peserta didik untuk belajar berpikir kritis dan memiliki keterampilan memecahkan masalah serta memperoleh pengetahuan (Shoimin, 2014: 130).

Abidin (2014: 161) menyatakan nilai lebih dari model pembelajaran berbasis masalah/PBM (problem based laerning) yaitu mampu mendorong peserta didik supaya lebih mampu berpikir tingkat tinggi dengan cara analisis, sintesis, dan evaluasi. Langkah-langkah dalam penerapan model pembelajaran berbasis masalah/PBM (problem based learning) mampu menumbuhkan kemampuan berpikir kritis. Model pembelajaran ini tidak sekedar model pembelajaran yang semata mata mengatasi kebosanan belajar dengan model konvensional, namun merupakan model yang punya peran mengembangkan kemampuan berpikir, khususnya berpikir untuk menyelesaikan masalah yang telah disajikan oleh guru.

$$
\text { Model pembelajaran berbasis }
$$
masalah/PBM (problem based learning) mampu mengubah pola pembelajaran teacher dominated learning menuju student dominated learning. Hal tersebut merupakan tuntutan kurikulum 2013. Pembelajaran berbasis masalah merupakan cara menciptakan keberhasilan belajar dengan beberapa alasan, salah satunya yaitu peserta didik terlibat aktif sehingga dapat menghasilkan basis terstruktur dalam pengetahuan apabila dibandingkan dengan pembelajaran tradisional, peserta didik juga dapat mempertahankan pengetahuan yang dipelajari lebih lama.

Keberhasilan lain penerapan model pembelajaran berbasis masalah/PBM (problem based learning) untuk menumbuhkan kemampuan berpikir kritis pada mata pelajaran PPKn. Model pembelajaran ini menuntut peserta didik secara individu maupun secara kelompok unyuk aktif memecahkan masalah dan menemukan solusi dengan mengekplorasi dari berbagai sumber pembelajaran tanpa dibatasi dan terfokus pada buku teks. Proses belajar yang menggunakan model pembelajaran berbasis masalah/PBM (problem based laerning) mengalami sendiri secara langsung pengalaman belajarnya. Kelebihan tersebut tercermin selama proses pembelajaran berlangsung yang lebih berpusat pada peserta didik, dengan cara mengoonstruksi pengetahuannya sendiri dengan memecahkan masalah dan mencari solusi terbaik atas permasalahan.

Implementasi model pembelajaran berbasis masalah/PBM (problem based learning) pada proses belajar dapat dilakukan secara individu dan kelompok. Abidin (2014, : 163-165) mengemukakan langkah-langkah penerapan model pembelajaran berbasis masalah/PBM (problem based laerning) yaitu: 1) prapembelajaran; 2) menemukan masalah; 3) membangun struktur kerja; 4) menetapkan masalah; 5) mengumpulkan berbagai informasi; 6) merumuskan solusi; 7) menemukan solusi terbaik; 8) menyajikan solusi; dan 9) pascapembelajaran.

Model pembelajaran berbasis masalah/PBM mampu menumbuhkan kemampuan berpikir kritis peserta didik. Model pembelajaran ini perlu diterapkan oleh guru PPKn dalam pencapaian hasil pembelajaran dan proses pembelajaran yakni berpikir kritis. Hal tersebut disebabkan karena dalam model 
pembelajaran ini, keberadaan masalah empiris menjadi kunci dalam penerapan model pembelajaran tersebut sehingga peserta didik dapat berpartisipasi dalam pembelajaran untuk memecahkan masalah. Untuk melakukan pemecahan masalah, peserta didik menggunakan pemikiran tingkat tinggi yakni berpikir kritis. Begitu juga lingkup kajian mata pelajaran PPKn berhubungan dengan permasalahan pada kehidupan sehari-hari dan membutuhkan kemampuan berpikir kritis untuk memecahkan permasalahan. Model berpikir kritis diperlukan supaya peserta didik mampu menjadi warga negara yang baik (good citizen) yang digunakan untuk menanggapi isu-isu kewarganegaraan.

Implementasi model pembelajaran berbasis masalah/PBM (problem based laerning) mampu menciptakan pola interaktif antara guru dan peserta didik. Pembelajaran dengan model ini peran guru hanya sebagai fasilitator, sehingga bukanlah satu-satunya sumber belajar bagi peserta didik. Dengan demikian dapat

Tabel 5. Rangkuman Hasil Uji t Sikap Demokratis Kelas Eksperimen dan Kelas Kontrol

\begin{tabular}{|c|c|c|c|c|c|c|}
\hline $\mathbf{N}$ & $\overline{\mathbf{X}}$ & $\mathbf{d b}$ & to & tt & \multicolumn{2}{|c|}{ Sig. } \\
\cline { 5 - 7 } & & & & & $\mathbf{0 , 0 5}$ & $\mathbf{0 , 0 1}$ \\
\hline 31 & 101,19 & 29 & 5,332 & 2,00 & $*$ & - \\
\hline 29 & 95,28 & 27 & & & & \\
\hline
\end{tabular}

Berdasarkan Tabel 5 dapat diketahui pada taraf signifikansi $\alpha=0,05$ (5,332>2,000). Hasil tersebut memperlihatkan ada pengaruh yang signifikan dengan menerapkan model pembelajaran berbasis masalah/PBM (problem based learning) dalam pembelajaran PPKn terhadap sikap demokratis peserta didik di Sekolah Menengah Kejuruan Negeri 1 Magelang. Hasil perbandingan gain score antara kelas yang dibelajarkan dengan model pebelajaran berbasis masalah (problem based learning) memperoleh skor yang lebih tinggi dibandingkan kelas yang dibelajarkan mengoptimalkan kemampuan peserta didik dan pembelajaran lebih bermakna. Berdasarkan paparan di atas, peneliti dapat menyimpulkan bahwa model pembelajaran berbasis masalah/PBM (problem based learning) dalam pembembelajaran PPKn berpengaruh terhadap kemampuan berpikir kritis peserta didik di Sekolah Menengah Kejuruan Negeri 1 Magelang.

Hipotesis kedua menyatakan bahwa "Terdapat pengaruh model pembelajaran berbasis masalah/PBM (problem based learning) dalam pembelajaran PPKn terhadap sikap demokratis peserta didik di Sekolah Menengah Kejuruan Negeri 1 Magelang". Analisis yang digunakan menggunakan uji t. Adapun untuk lebih mudah memahami hasil uji $t$ sikap demokratis kelas eksperimen dan kelas kontrol berikut kami sajikan tabel rangkuman di bawah ini.

dengan model pembelajaran penemuan (discovery learning). Perolehan gain score pada kelas eksperimen yang diberikan perlakuan (treatmen) dengan menggunakan model pembelajaran berbasis masalah/PBM (problem based learning) sebesar 0,72 dalam kategori efektif tinggi, sedangkan kelas kontrol memperoleh gain score yang diajar dengan menggunakan model pembelajaran penemuan (discovery learning) sebesar 0,40 yang dikategorikan sedang. Hasil perbandingan gain score sikap demokratis disajikan pada gambar di bawah ini. 


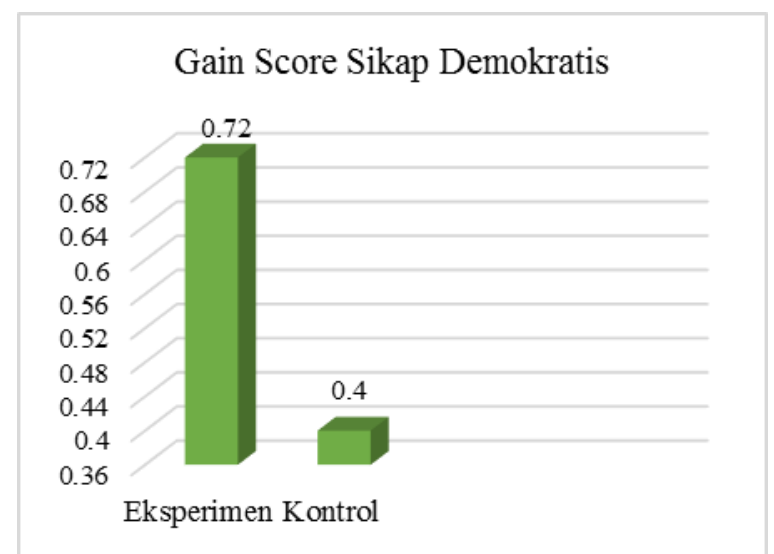

Gambar 3. Perbandingan Gain Score Sikap Demokratis

Perbandingan sikap demokratis antara peserta didik dalam proses pembelajaran PPKn yang dibelajarkan dengan model pembelajaran berbasis masalah/PBM (problem based learning) dengan peserta didik yang diajar dengan model pembelajaran penemuan (discovery learning) dapat dilihat berdasarkan nilai rata-rata (mean) sebelum dilakukan perlakuan dengan setelah dilakukan perlakuan. Perolehan skor mean kemampuan awal (pre-test) peserta didik pada kelas eksperimen memperoleh nilai rata-rata sebesar 84,35 sedangkan skor mean kelas kontrol memperoleh nilai 85,76. Skor kemampuan akhir (post-test) peserta didik pada kelas eksperimen memperoleh skor mean 101,19 sedangkan skor mean kelas kontrol memperoleh 95,28. Hasil tersebut menunjukkan bahwa kedua model pembelajaran baik pada kelas eksperimen yang diberikan perlakuan dengan model pembelajaran berbasis masalah/PBM (problem based learning) dengan kelas kontrol yang diajarkan dengan model pembelajaran penemuan (discovery learning) sama-sama dapat menciptakan sikap hidup yang demokratis peserta didik. Hasil perbandingan nilai rata-rata (mean) sikap demokratis kami sajikan pada gambar skor mean di bawah ini.

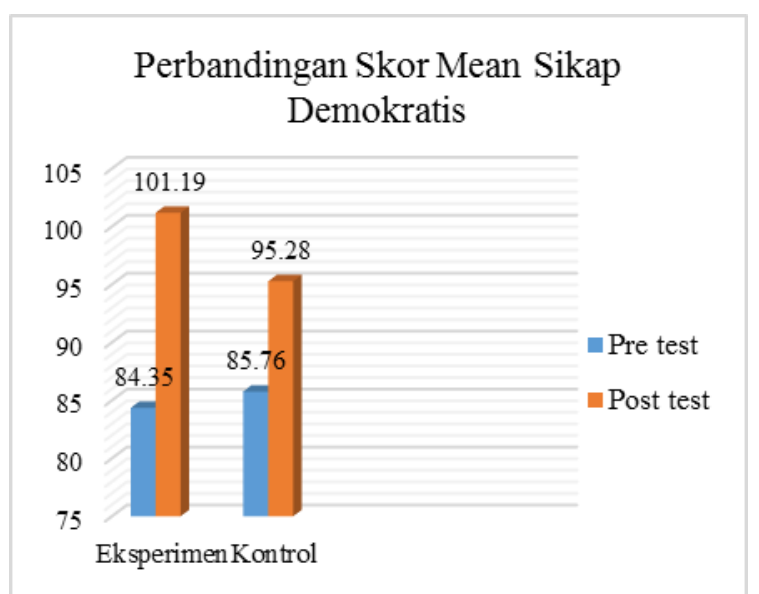

Gambar 4. Perbandingan Skor Mean Sikap Demokratis

Hasil penelitian ini dapat menguatkan penelitian sebelumnya yang dilakukan oleh Purnomo, Lasmawan, \& Suarni (2015: 1) bahwa terdapat perbedaan yang signifikan sikap demokrasi peserta didik kelas VI MI
Al Miftah pada pelajaran IPS antara peserta didik yang mengikuti model pembelajaran berbasis masalah/PBM dan peserta didik yang mengikuti model pembelajaran konvensional. Selain itu, hasil penelitian ini 
sesuai dengan hasil penelitian sebelumnya yang dilakukan oleh Prasetyo (2012: 111) yang menunjukkan bahwa prestasi belajar PKn berpengaruh secara postif dan signifikan terhadap sikap demokratis peserta didik kelas XI Sekolah Menengah Kejuruan Negeri 1 Yogyakarta. Hal tersebut dibuktikan dengan adanya nilai koefisien korelasi product moment sebesar 0,313 dan nilai koefisien determinasi sebesar $9,8 \%$ yang menyatakan bahwa sikap demokratis peserta didik dipengaruhi oleh prestasi belajar Pendidikan Kewarganegaraan peserta didik sebesar $9,8 \%$.

Hasil penelitian yang menyatakan terdapat pengaruh model pembelajaran berbasis masalah/PBM (problem based laerning) terhadap sikap demokratis peserta didik dalam pembelajaran PPKn di Sekolah Menengah Kejuruan Negeri 1 Magelang diperkuat dengan pandangan teoretis. Model pembelajaran berbasis masalah/PBM (problem based learning) memungkinkan peserta didik untuk melakukan komunikasi ilmiah dalam kegiatan diskusi atau presentasi. Masalah yang disajikan dalam pembelajaran berbasis masalah disajikan sebagai fokus pembelajaran yang dapat diselesaikan peserta didik melalui kerja kelompok sehingga dapat memberi pengalaman-pengalaman belajar yang beragam pada peserta didik seperti kerja sama dan interaksi kelompok. Model pembelajaran berbasis masalah/PBM (problem based learning) dilakukan melalui pembelajaran yang menekankan aktivitas kolaboratif, komunikatif, dan kooperatif.

Pencapaian keberhasilan proses pembelajaran dengan menerapkan model pembelajaran berbasis masalah/PBM (problem based laerning) tidak hanya pada kemampuan berpikir kritis namun juga pada sikap demokratis. Dengan kedua keberhasilan yang dimiliki peserta didik yaitu kemampuan berpikir kritis dan sikap demokratis, peserta didik dapat berkembang sesuai kemampuannya dalam mengelola materi pembelajaran. Penerapan model pembelajaran ini di kelas dapat menumbuhkan kemampuan dan keterampilan komunikasi serta peserta didik dapat bekerja sama dengan anggota kelompok. Dengan demikian, penerapan model pembelajaran berbasis masalah/PBM (problem based learning) akan menciptakan iklim pembelajaran yang demokratis sehingga dapat menumbuhkan sikap demokratis peserta didik. Masalah yang menjadi kunci dalam penerapan model pembelajaran ini dapat dipecahkan oleh peserta didik melalui kegiatan diskusi. Dalam kegiatan diskusi peserta didik dapat berargumen dengan kepekaan yang tinggi dan terbuka dalam pemecahan masalah. Dalam kegiatan ini, peserta didik dikondisikan dalam kegiatan belajar yang demokratis sehingga pada akhirnya akan menumbuhkan sikap demokratis. Berdasarkan uraian tersebut, dapat disimpulkan bahwa model pembelajaran berbasis masalah/PBM (problem based learning) dalam pembembelajaran PPKn berpengaruh terhadap sikap demokratis peserta didik dalam pembelajaran PPKn di Sekolah Menengah Kejuruan Negeri 1 Magelang.

\section{SIMPULAN DAN SARAN}

\section{Simpulan}

Berdasarkan hasil penelitian dan pembahasan di atas dapat dikemukakan beberapa simpulan yaitu. (1) Terdapat pengaruh yang signifikan model pembelajaran berbasis masalah/PBM (problem based learning) terhadap kemampuan berpikir kritis peserta didik dalam pembelajaran Pendidikan Pancasila dan Kewarganegaraan di Sekolah Menengah Kejuruan Negeri 1 Magelang pada KD menganalisis kasus pelanggaran hak dan pengingkaran kewajiban sebagai warga negara. Hal ini dibuktikan dari nilai t-hitung lebih besar dari t-tabel pada taraf signifikansi $\alpha=0,05$ $(2,557>2,000)$. Peserta didik kelas eksperimen yang diajar dengan menggunakan model pembelajaran berbasis masalah/PBM (problem based learning) memperoleh gain score sebesar 0,59 dalam kategori efektif sedang, sedangkan 
peserta didik kelas kontrol yang diajar dengan menggunakan model pembelajaran penemuan (discovery learning) memperoleh gain score sebesar 0,39 dalam kategori efektif sedang.

Berdasarkan hasil analisis tersebut, model pembelajaran berbasis masalah/PBM (problem based learning) lebih efektif daripada model pembelajaran penemuan (discovery learning) untuk menumbuhkan kemampuan berpikir kritis peserta didik dalam pembelajaran PPKn di Sekolah Menengah Kejuruan Negeri 1 Magelang. (2) Terdapat pengaruh yang signifikan model pembelajaran berbasis masalah/PBM (problem based learning) terhadap sikap demokratis peserta didik dalam pembelajaran PPKn di Sekolah Menengah Kejuruan Negeri 1 Magelang pada KD menganalisis kasus pelanggaran hak dan pengingkaran kewajiban sebagai warga negara. Hal ini dibuktikan dari nilai t-hitung lebih besar dari t-tabel pada taraf signifikansi $\alpha=0,05$ $(5,332>2,000)$. Peserta didik kelas eksperimen yang diajar dengan menggunakan model pembelajaran berbasis masalah/PBM (problem based learning) memperoleh gain score sebesar 0,72 dalam kategori efektif tinggi, sedangkan peserta didik kelas kontrol yang diajar dengan menggunakan model pembelajaran penemuan (discovery learning) memperoleh gain score sebesar 0,40 dalam kategori efektif sedang. Berdasarkan hasil analisis tersebut maka, model pembelajaran berbasis masalah/PBM (problem based learning) lebih efektif daripada model pembelajaran penemuan (discovery learning) untuk menumbuhkan sikap demokratis peserta didik dalam pembelajaran PPKn di Sekolah Menengah Kejuruan Negeri 1 Magelang.

\section{Saran}

Berdasarkan hasil dari beberapa penelitian tentang penerapan model pembelajaran berbasis masalah/PBM terbukti lebih efektif dan mampu menumbuhkan sikap demokratis dan berfikir kritis. Sudah seharusnya guru PPKn menerapkan model pembelajaran ini mengantikan model pembelajaran konvensional ceramah. Selain itu, untuk lebih membuktikan keekektifan model ini perlu dilakukan penelitain serupa dengan Kompetensi Dasar (KD) yang berbeda. Hal tersebut perlu dilakukan mengingat penelitian ini hanya terbatas pada 1 (satu) KD yakni menganalisis kasus pelanggaran hak dan pengingkaran kewajiban sebagai warga negara

\section{DAFTAR PUSTAKA}

Abidin, Y. (2014). Desain Sistem Pembelajaran dalam konteks Kurikulum 2013. Bandung: PT Refika Aditama.

Center for Civic Education. 1994. National standards for Civics and Government. Calabasas: CCE.

Cholisin. (Mei 2005). Pengembangan paradigma baru Pendidikan Kewarganegaraan Civic Education) dalam praktek pembelajaran kurikulum berbasis kompetensi. Makalah disajikan dalam Training of Trainers (ToT) Nasional Guru Mata Pelajaran PKn, di Asrama Haji Surabaya. http://staffnew.uny.ac.id/upload/131 474282/penelitian/PARADIGMA+B ARU+ PKN_0.pdf. Diunduh tanggal 30 Oktober 2017.

Feriandi, Y. A. (2017). Revitalisasi moral kewarganegaraan dalam ungkapan Jawa sebagai sumber pembentukan civic culture dan politic culture. Jurnal Civics: Media Kajian Kewarganegaraan, 14(2), 176-182.

Isaac, S. \& Michael, W.B. (1981). Handbook in research and evaluation: for education and the behavioral sciences, second edition. San Diego: Edits Publishers.

Kemendikbud. (2014). Materi pelatihan implementasi kurikulum 2013 guru SMA/SEKOLAH MENENGAH KEJURUAN/MA/MAK mata pelajaran PPKn. Jakarta: BPSDMP \& PMP.

Massa, N.M. (2008). Problem-based learning (pbl): a real-world antidote to the standart and testing regime. The New England Journal of Higher Education. 22 (4), 19-20.

Murdiono, M. (2010). Peningkatan keterampilan kewarganegaraan (civic 
Citizenship Jurnal Pancasila dan Kewarganegaraan Vol 6 No 2 Oktober 2018, hal hal 126-139 Avaliable online at : http://e-journal.unipma.ac.id/index.php/Citizenship Print ISSN: 2302-433X Online ISSN : 2579-5740

skills) melalui penerapan strategi pembelajaran berbasis masalah (problem based learning). Jurnal Penelitian Ilmu Pendidikan, 3 (1), 16-29.

Prasetyo, G.E. (2012). Pengaruh prestasi belajar Pendidikan Kewarganegaraan terhadap sikap demokratis siswa kelas XI SEKOLAH MENENGAH KEJURUAN Negeri 1 Yogyakarta tahun ajaran 2010/2011. Jurnal Citizenship. 1 (2), 105-112.

Purnomo, R. Lasmawan, I.W. \& Ni Ketut Suarni, N.K. (2015). Pengaruh model pembelajaran berbasis masalah/PBM terhadap sikap demokratis dan hasil belajar IPS kelas VI MI Al Miftah Denpasar. Jurnal Pendidikan Dasar. 5 (1), 1-7.

Rosyada, D. (2004). Paradigma Pendidikan Demokratis. Jakarta: Prenada Media.

Samsuri. (September 2013). Paradigma Pendidikan Kewarganegaraan dalam Kurikulum 2013. Makalah disajikan dalam Kuliah Umum Program Studi Pendidikan Pancasila dan Kewarganegaraan, di FKIP Universitas Ahmad Dahlan. http://staffnew.uny.ac.id/upload/132 300167/pengabdian/paradigmapendidikan-kewargane garaankurikulum-2013-kuliah-umum-fkipuad-15-september-2013.pdf.

Diunduh tanggal 30 Oktober 2017.

Shoimin, A. (2014). 68 Model pembelajaran inovatif dalam Kurikulum 2013. Yogyakarta: Arr-Ruzz Media.

Somantri, M.N. (2001). Menggagas pembaharuan pendidikan IPS. Bandung: Remaja Rosdakarya.

\section{Soenarjo, S. (2013). MEMBANGUN KEHIDUPAN DEMOKRASI MELALUI PENDIDIKAN KEWARGANEGARAAN. Citizenship Jurnal Pancasila dan Kewarganegaraan, 2(1), 112-118.}

Sugiyono. (2013). Metode penelitian kuantitatif kualitatif dan $R \& D$.Bandung: CV Alfabeta.

Marzuki, M., \& Feriandi, Y. A. (2016). Pengaruh Peran Guru Ppkn dan Pola Asuh Orang Tua terhadap Tindakan Moral Siswa. Jurnal Kependidikan: Penelitian Inovasi Pembelajaran, 46(2), 193-206.

Suprihatiningrum, J. (2012). Strategi pembelajaran teori dan aplikasi. Yogyakarta: Ar-Ruzz Media.

Tan, O.S. (2003). Problem-based learning innovation: using problem to power learning in the $21^{\text {st }}$ century. Singapore: Thompson Learning.

Winataputra, U.S. (2012). Pendidikan Kewarganegaraan dalam perspektif pendidikan untuk mencerdaskan kehidupan bangsa (gagasan, instrumentasi, dan praksis). Bandung: Widya Aksara Press.

Yang, S.C. \& Chung, T.Y. (2009). Experimental study of teaching critical thinking in civic education in Taiwanese junior high school. British Journal of Educational Psychology. 79 (1), 29-55.

Yoswita, F.D., Pramudiyanti, \& Marpaung, R.R. T. (2014). Pengaruh model pembelajaran problem based learning (pbl) terhadap kemampuan berpikir kritis siswa. Jurnal Bioterdidik. 2 (6), 1-10. 